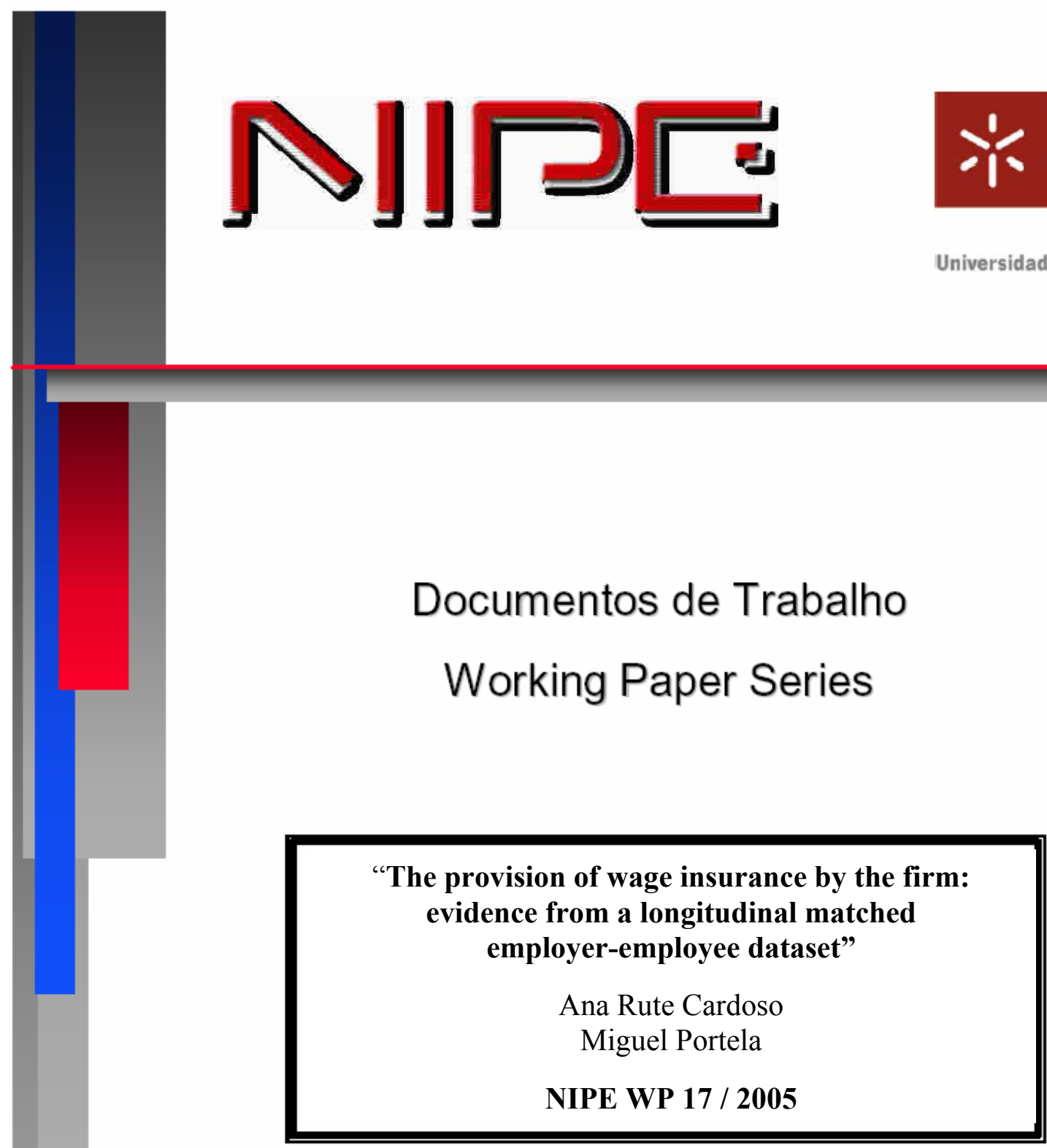

NÚCLEO DE INVESTIGAÇÃO EM POLITICAS ECONÓMICAS

UNIVERSIDADE DO MINHO 


\title{
"The provision of wage insurance by the firm: evidence from a longitudinal matched employer-employee dataset"
}

\author{
Ana Rute Cardoso \\ Miguel Portela
}

NIPE ${ }^{*}$ WP 17 / 2005

URL:

http://www.eeg.uminho.pt/economia/nipe/documentostrabalho.php

\footnotetext{
* NIPE - Núcleo de Investigação em Políticas Económicas - is supported by the Portuguese Foundation for Science and Technology through the Programa Operacional Ciencia, Teconologia e Inovação (POCTI) of the Quadro Comunitário de Apoio III, which is financed by FEDER and Portuguese funds.
} 


\title{
The provision of wage insurance by the firm: evidence from a longitudinal matched employer-employee dataset *
}

\author{
Ana Rute Cardoso \\ IZA Bonn, University of Minho, and CEPR ${ }^{\dagger}$ \\ and \\ Miguel Portela \\ Tinbergen Institute, NIPE-University of Minho, and IZA Bonn
}

November 2005

\begin{abstract}
We evaluate the impact of product market uncertainty on workers wages, addressing the questions: To what extent do firms provide insurance to their workforce, insulating their wages from shocks in product markets? How does the amount of insurance provided vary with firm and worker attributes? We use a longitudinal matched employer-employee dataset of remarkable quality. The empirical strategy is based on Guiso et al. (2005). We first estimate dynamic models of sales and wages to retrieve consistent estimates of shocks to firms' sales and to workers' earnings. We are then able to estimate the sensitivity of wages to permanent and transitory shocks to firm performance. Results point to the rejection of the full insurance hypothesis. Workers' wages respond to permanent shocks to firm performance, whereas they are not sensitive to transitory shocks. Managers are not fully insured against transitory shocks, while they receive the same protection against permanent shocks as workers in other occupations. Firms with higher variability in their sales, and those operating in different industries, offer more insurance against permanent shocks. Comparison with Guiso et al. (2005) indicates that Portuguese firms provide less insurance than Italian firms, corroborating evidence on the high degree of wage flexibility in Portugal.
\end{abstract}

KEYWORDS: product market uncertainty; wage shocks; risk sharing; wage insurance. JEL CODES: C33, D21, J33, J41.

\footnotetext{
${ }^{*}$ We thank Lorenzo Cappellari for providing us with his presentation to the $5^{\text {th }}$ UK meeting of Stata users on minimum distance estimation. The second author acknowledges financial support from Fundação para a Ciência e a Tecnologia, under the grant SFRH/BD/5114/2001. Part of this work was carried out while he was visiting IZA Bonn, whose support is gratefully acknowledged. We are grateful to the Ministry of Employment, Statistics Department, for access to the data.

${ }^{\dagger}$ Corresponding author: Ana Rute Cardoso, IZA, Schaumburg-Lippe-Str. 7/9, 53113 Bonn, Germany. E-mail: cardoso@iza.org
} 


\section{Introduction}

To which extent do firms provide wage insurance to their workers, insulating them from shocks in product markets? Theoretical handling of the issue now spans for several decades, but progress on the empirical front has been held back by very strict requirements on micro data.

Insurance models can explain why, following a change in demand, wages do not adjust as much as predicted by spot market theory. The underlying idea is that risk neutral firms commit to paying a pre-defined wage to their risk averse workers, independently of product market fluctuations. Such strategy is profit maximizing because risk-averse workers will accept a non-stochastic wage lower than the expected value of a stochastic wage. A central issue concerns the enforceability of insurance contracts. Building on early insurance models, implicit contract theory has established conditions under which it is in the firm's and in the worker's interest to stick to the contract. Basically, workers and firms will respect the contract as long as its long run gains outweigh the short term benefit from reneging it. Section 2 provides an overview of the theoretical literature.

Empirical studies, which initially relied on aggregate industry data (Gamber 1988, Christofides and Oswald 1992, Blanchflower et al. 1996) progressed to use firm-level average data (Hildreth and Oswald 1997, Nickell and Wadhwani 1990). Beaudry and DiNardo (1991) used individual data on workers, but their indicator of market conditions is computed at the aggregate or industry level. Similarly, Weinberg (2001) uses individual data to study the impact of displacement on wages, but relies on a measure of shocks defined at the industry level to analyze wage and employment fluctuations at the industry level in response to demand shocks. Devereux (2005) relies on panel data on workers to quantify the impact of industry-level demand shocks on wages, finding that industry wages respond positively to changes in industry employment. Finally, Guiso et al. (2005) have set a new benchmark in the analysis of this issue. Their ingenious empirical identification strategy relies on longitudinal matched employer-employee data to estimate 
dynamic panel data models and quantify the impact of temporary and permanent firm-level shocks on wages. They found that firms provide full insurance against temporary shocks, while providing only partial insurance against permanent shocks. We will follow their empirical strategy with adaptations to analyze the provision of wage insurance by the firm.

We use a longitudinal matched employer-employee dataset of remarkable quality, which matches all the firms and workers in the manufacturing and services private sectors in Portugal. Several advantages of this rich data set can be highlighted. Given that it reports every company and every worker in the industries it covers, problems commonly faced by longitudinal data sets, such as panel attrition and under- or over-representation of certain groups, are avoided. Also, the legal requirement for the data to be posted in a visible location within the company contributes to its reliability, reducing measurement errors.

After the brief revision of the theoretical literature that follows, section 3 describes the institutional framework for wage setting in Portugal and section 4 describes the data. Sections 5 to 7 summarize the empirical model and present the results, before concluding comments are presented in section 8 .

\section{Wage insurance in the theoretical literature}

Theoretical models have long addressed the mechanisms why companies do not adjust wages as much as predicted by spot labor market theory, once faced with shocks in product demand. The issue of enforceability of contracts has deserved particular attention, to establish conditions under which firms and workers will stick to a pre-defined contract.

In the models by Baily (1974), Gordon (1974), and Azariadis (1975), workers are risk-averse and firms are risk-neutral, worker performance is verifiable, and job mobility is costly. As such, firms commit to paying a pre-defined wage to their workers, independently of product market fluctuations. That strategy maximizes profits, since risk-averse workers will accept a non-stochastic wage lower than the expected value of a stochastic wage. Much earlier, Knight (1921) had argued 
that wages are contractually set in advance at a fixed rate, whereas profits are determined residually, bearing all the risk of fluctuations in demand.

Gamber (1988) allows for bankruptcy and distinguishes between temporary and permanent shocks, in a two-period model. The possibility of bankruptcy constrains the capacity of the firm to provide insurance to the workers. Gamber finds that real wages react more to permanent shocks than to temporary ones. Unlike permanent shocks, temporary shocks hold for just one period, and therefore the firm wishing to smooth the wage of the worker over time promotes a relatively small wage adjustment in the period the shock occurs, deferring the rest of the adjustment to the following period.

The issue of enforceability of contracts has been extensively handled by contract theory (for an overview, see Rosen 1985). If worker performance is not verifiable, the firm may gain from declaring that it is below its actual level and reneging the contract, thus paying a wage lower than the insurance wage. The firm would stick to the contract only if its long run gains outweighed the short term benefit from reneging it. Similarly, if worker mobility is allowed, the worker might gain from reneging the contract and accepting a better outside offer. Implicit contract theory establishes conditions under which it is in the firm's and in the worker's interest to stick to the contract. Weiss (1984) concentrates on the role of worker mobility costs, showing that, in particular when workers have imperfect access to capital markets, the higher the mobility costs, the more insurance firms can provide. Workers will stick to the contract as long as mobility costs-for example, loss of specific human capital - outweigh the short-run gains from outside wage opportunities. In the model by Holmstrom (1981), once the firm reneges a labor contract, the loss of reputation will force it to buy labor services at prices closer to those of the spot market; in the model by Thomas and Worrall (1988), it will be forced to buy labor on the spot market forever after. The firm will not be willing to incur that "penalty" if the spot market wage is sufficiently high compared to the insurance wage. The insurance wage could therefore fluctuate between the level strictly required to prevent the firm from dismissing the worker and, by a 
similar reasoning, the level strictly required to prevent the worker from quitting. The latter case holds when contracts are not binding on the worker, whereas the former holds when contracts are not binding on the firm. In the model by Harris and Holmstrom (1982), firms do not have reputation concerns, but they learn about worker ability and adjust the wage to prevent the worker from quitting, increasing it when the outside market wage is higher than the current wage.

Beaudry and DiNardo (1991) find evidence that supports this reasoning. They find that lower "historical" unemployment rates since the worker was hired are associated with higher current wages, arguing that, since workers can quit to accept a better wage offer in good times, their wage must be set higher in good times. On the contrary, they do not find support for the alternative hypothesis that wages are set in a spot market (in which case they would be sensitive just to the contemporaneous unemployment rate) or set under full insurance conditions (in which case they would be sensitive just to the unemployment rate at the time of hiring).

Several reasons why workers are less able to bear risks than stockholders have been pointed out. For example, workers usually have lower wealth and less access to financial markets where to diversify risk, and they have lower expertise on financial issues.

The insurance provided can vary across types of firms or workers. The share of risk borne by the firm will depend crucially on factors such as: the possibilities of access to financial markets by workers and firms; the persistence of the shocks hitting the firm; workers' and firms' preferences, namely their degree of risk-aversion; the sensitivity of firm output to worker effort, with the wages of crucial workers (i.e. managers) more closely linked to firm performance, and therefore subject to less insurance provision; the amount of firm resources involved in training the worker; the probability that the firm will go bankrupt; the possibility of monitoring output, i.e. the precision of the signal on the agent's effort, with more precision leading to less insurance (Guiso et al. (2005) have computed the noise on performance as the variability over time in the performance of the firm). 


\section{$3 \quad$ Wage setting institutions in Portugal}

The Portuguese labor market is characterized by a high level of employment rigidity and remarkable wage flexibility. In fact, its strict job protection legislation, covering issues such as advance notice required before dismissal, severance pay, and the rules on use of fixed-term or temporary contracts, invariably place the country among the OECD economies with highest employment rigidity (see for example OECD 1999). On the contrary, the country ranks among the OECD economies with highest wage flexibility (see OECD 1992), as wages are highly responsive to the unemployment rate, despite the regulated framework.

Collective bargaining covers almost all of the workforce, even though union membership has declined, from 61 percent in 1970 and 1980 to 32 percent in 1990 (OECD 1994: 184). This wide coverage results from widespread mechanisms of extension of contracts: most often, employers who subscribe to an agreement apply it to all of their workforce, irrespective of the worker union membership status; employers or workers representatives can join an existing agreement, subscribing to a contract they had initially not signed; moreover, the Government can impose mandatory extensions of existing contracts, when workers are not covered by a trade union, when one of the parties refuses to negotiate or negotiation is obstructed in any other way.

Studies at the micro level have identified sources of wage flexibility under this regulated setting. In particular, Cardoso and Portugal (2005) have found that wages set by collective bargaining reflect to a high extent the degree of power of the partners negotiating, but subsequent firm-specific arrangements reduce the returns to union power, adjusting wages to the conditions that prevail at the micro level. Also, Cardoso (1999) had found that the returns to different worker attributes vary widely across firms.

As a rule, wage negotiations are held yearly and the wage updates take effect in January each year. 


\section{Data set and concepts used}

Quadros de Pessoal is a matched employer-employee data set gathered by the Ministry of Employment, based on an inquiry that every company with wageearners is legally obliged to fill in. Public administration and domestic service are not covered, and the coverage of agriculture is low, given its low share of wageearners. For the remaining sectors, the mandatory nature of the survey leads to an extremely high response rate. Each year, around two million workers and 100 to 200 thousand companies are covered. Data for 1991 to 2000 are used.

Reported data cover the firm and all the workers engaged in the firm in a reference week (whether wage-earner, unpaid family member of owners working in the firm). Reported variables include the firm's location, industry, employment, sales volume, ownership structure, and date of creation, and the worker's gender, schooling, age, occupation, skill, date of admission into the company, several components of wage, duration of work, and collective bargaining contract.

A worker identification code, based on a transformation of the social security number, enables tracking him/her over time. Extensive checks have been performed to guarantee the accuracy of the data, using gender, date of birth, and highest schooling level achieved. A firm identification code enables tracking it over time. Based in particular on the location of the firm and its official identification codes, extensive controls are implemented by the data gathering agency to guarantee that a firm is not assigned a different number later on.

Gross hourly earnings were computed as

$$
\text { monthw }=b w+s e n+r e g,
$$

where $b w$ stands for base-wage, sen are seniority-indexed components of pay, and reg are other regularly paid components. Wages were deflated using the Consumer Price Index.

A major issue concerns the empirical measurement of fluctuations in product markets. The shock affecting the firm has been defined using: the industry output price (Gamber 1988) (Christofides and Oswald 1992); the industry profit (Blanch- 
flower et al. 1996) (Christofides and Oswald 1992); firm profits, in studies that rely however on wage data also aggregated for the firm level (Hildreth and Oswald 1997) (Nickell and Wadhwani 1990). Abowd and Lemieux (1993) rely on a set of assumptions to compute a profitability variable (quasi-rents per worker) at the firm level, and use the price of exports and imports at the industry level to instrument it. Guiso et al. (2005) use value added instead of profits, arguing that it is the variable directly subject to stochastic fluctuations, being more reliable than profits. A similar option was taken by Estevão and Tevlin (2003), who nevertheless used industry data. Holzer and Montgomery (1993) used firm sales, with wages averaged for the firm level. We use sales as our indicator of firm performance, arguing that it captures demand uncertainty, as shocks in product demand are directly reflected in changes in sales. Given fluctuations in demand, output could remain unchanged if prices would adjust fully and instantaneously, but since that is not the case, output will undergo fluctuations (Baily 1974). Sales were deflated using the GDP deflator.

Details on the construction of the database, sample sizes, and descriptive statistics are presented in appendix.

\section{$5 \quad$ Firm performance}

Based on the specification used by Guiso et al. (2005), firms' performance is modeled as

$$
\text { Sales }_{j t}=\gamma_{t}+\rho \text { Sales }_{j, t-1}+X_{j t}^{\prime} \Gamma+\eta_{j}+\epsilon_{j t}
$$

where Sales $_{j t}$ is the logarithm of sales of firm $j$ in period $t, X_{j t}$ is a vector of firm characteristics that includes a set of industry and location dummies, $\gamma_{t}$ represents period $t$ specific constant, $\rho$ and $\Gamma$ are parameters to be estimated, $\eta_{j}$ is the firm specific effect, and $\epsilon_{j t}$ is the remaining component of the error term.

Estimation of equation (1) by OLS or the usual panel models, fixed or random effects, is inconsistent in the presence of the lagged dependent variable, since, by definition, Sales $s_{j-1}$ is correlated with $\eta_{j}$. Following Arellano and Bond (1991), 
one possible solution is to take first differences, eliminating the fixed effect, and then estimate equation (1) using a generalized method of moments (GMM) procedure. The set of instruments include lagged levels of the dependent variable and the remaining regressors. The span of the lag of the dependent variable depends on the serial correlation observed in the residuals of the model.

This solution has poor finite sample properties concerning bias and precision when the available instruments are weak. Blundell and Bond (1998) show that the solution of Arellano and Bond (1991) has a large downward finite-sample bias when the time series are persistent and the number of periods is small. An alternative solution is to implement a system GMM estimation, for first-differences and levels, as argued by Blundell and Bond (1998). Compared to the first-differenced estimator, the system estimator assumes additionally that the first-differences of the lagged dependent variable, and explanatory variables, are not correlated with the firms' specific effects, $\eta_{j}$. So, lagged first-differences can be used as instruments in the level equations for the lagged dependent variable, and first-differences of the explanatory variables are also valid instruments. Again the extent of the lag depends on residuals' serial correlation.

We estimate equation (1) using the system GMM procedure based on the following instruments: (i) Sales $_{j, t-3}$ and earlier levels of this variable, in the equations in first-differences; (ii) $\Delta$ Sales $_{i, t-2}$ in the equations in levels. The remaining regressors are treated as exogenous, and introduced in levels as instruments. Following the correction proposed by Windmeijer (2005), we report in Table 1 the results for the 2-step GMM estimation procedure.

Sales are relatively persistent over time, with a coefficient on lagged sales of .62. Our results indicate that industry dummies are jointly significant, just like time dummies and region dummies. According to the Sargan test, we do not reject the validity of our instruments at the $1 \%$ and $5 \%$ levels. The serial correlation in the first-differenced residuals indicates that we should be using lagged levels of sales dated $t-3$ and earlier, as we do.

In Table 2 we report the autocovariance structure for $\Delta \epsilon_{j t}$. The results confirm 
Table 1: Sales regression

\begin{tabular}{rcc}
\hline \hline Variable & Estimate & \\
\hline Log sales at t-1 & .617 & $(.032)$ \\
Region dummies & 8.901 & {$[.064]$} \\
Industry dummies & 114.2 & {$[.000]$} \\
Year dummies & 109.7 & {$[.000]$} \\
Sargan & 47.05 & {$[.068]$} \\
Sargan-df & 34 & \\
AR $(1)$ & -18.82 & {$[.000]$} \\
AR $(2)$ & 6.341 & {$[.000]$} \\
AR $(3)$ & 1.294 & {$[.196]$} \\
AR $(4)$ & -.842 & {$[.400]$} \\
AR $(5)$ & -.213 & {$[.831]$} \\
AR $(6)$ & .850 & {$[.395]$} \\
AR $(7)$ & -1.081 & {$[.280]$} \\
Firms & 17103 & \\
\hline \hline
\end{tabular}

The regression has been estimated by the system GMM procedure discussed in Blundell and Bond (1998). The instruments are discussed in the text. The dependent variable is log real sales. Robust standard errors reported in parentheses; $p$-values in brackets. For region, industry and year dummies, the joint $F-$ statistic is reported. Sargan-df stands for the degrees of freedom of the Sargan test. AR shows the test for serial correlation in the first-differenced residuals.

Table 2: Firms' autocovariances

\begin{tabular}{ccc}
\hline \hline$\tau$ & $E\left(\Delta \epsilon_{j t}, \Delta \epsilon_{j, t-\tau}\right)$ & Standard error \\
\hline 0 & .8601 & .0170 \\
1 & -.3828 & .0098 \\
2 & -.0665 & .0117 \\
3 & .0105 & .0087 \\
4 & .0134 & .0083 \\
5 & -.0073 & .0079 \\
6 & -.0001 & .0075 \\
7 & -.0008 & .0079 \\
\hline \hline \multicolumn{2}{l}{ The autocovariances are computed using all } \\
years pooled.
\end{tabular}


our choice of instruments. After 3 lags the covariance of first-differenced residuals is insignificant. These results are of particular interest for the specification of the structure of the error term which will take place in Section 7.

\section{Worker earnings}

Workers' wages are specified as

$$
W a g e_{i j t}=\phi_{t}+\delta W a g e_{i j, t-1}+K_{i j t}^{\prime} \Phi+\varphi_{i}+\alpha P_{j t}+\beta T_{j t}+\psi_{i j t}
$$

where Wage $e_{i j t}$ stands for the logarithm of monthly wage of worker $i$ engaged in firm $j$ in period $t$, and $K$ includes industry, region, education, and gender dummies, as well as age and age squared. The first component of the error term is the worker specific effect, $\varphi_{i}$. Following Guiso et al. (2005), we include in the wage regression the permanent and transitory components of firm specific shock, $P_{j t}$ and $T_{j t}$, respectively. The parameters $\alpha$ and $\beta$ capture the impact of these shocks on wages. Finally, $\psi_{i j t}$ is the remaining component of the error term not captured by the worker specific effect or the firm specificities. In the current section we concentrate on estimation and analysis of the composite error term $\omega_{i j t}=\varphi_{i}+\alpha P_{j t}+\beta T_{j t}+\psi_{i j t}$, and delay to section 7 further analysis of the different components.

Again, we have used the system GMM procedure to estimate equation (2). We use levels of wage lagged 4 periods and earlier as instruments for first-differenced equations, and lagged 3 periods first-differences of wages as instruments for equations in levels. The remaining regressors are assumed exogenous and introduced in levels. The results for the corrected 2-step system GMM estimation are reported in Table $3 .^{1}$

Wages show a high degree of persistence, with a coefficient on lagged wage above .8. Industry dummies are not jointly significant, while region dummies are marginally insignificant at the $10 \%$ level. The test for overidentifying restrictions

\footnotetext{
${ }^{1}$ We have considered each employment spell as a pair worker-firm, since we are interested in the provision of wage insurance by a given firm, and not the overall insurance the worker may enjoy when switching firms.
} 
Table 3: Wage regression

\begin{tabular}{rcc}
\hline \hline Variable & Estimate & \\
\hline Log wage at t-1 & .814 & $(.066)$ \\
Region dummies & 7.684 & {$[.104]$} \\
Industry dummies & 5.497 & {$[.856]$} \\
Year dummies & 57.52 & {$[.000]$} \\
Sargan & 26.85 & {$[.139]$} \\
Sargan-df & 20 & \\
AR(1) & -13.77 & {$[.000]$} \\
AR(2) & 6.989 & {$[.000]$} \\
AR(3) & -2.208 & {$[.027]$} \\
AR(4) & 1.727 & {$[.084]$} \\
AR(5) & -.618 & {$[.537]$} \\
AR(6) & .692 & {$[.489]$} \\
AR(7) & -1.160 & {$[.246]$} \\
Observations & 129316 & \\
Individuals & 30659 & \\
\hline \hline
\end{tabular}

The dependent variable is log real monthly wage. See the note to Table 1 .

Table 4: Workers' autocovariances

\begin{tabular}{ccc}
\hline \hline$\tau$ & $E\left(\Delta \omega_{j t}, \Delta \omega_{j, t-\tau}\right)$ & Standard error \\
\hline 0 & .0600 & .0014 \\
1 & -.0298 & .0009 \\
2 & -.0034 & .0001 \\
3 & -.0011 & .0009 \\
4 & .0005 & .0007 \\
5 & -.0001 & .0008 \\
6 & .0015 & .0010 \\
7 & -.0016 & .0013 \\
\hline \hline
\end{tabular}

The autocovariances are computed using all years pooled. $\Delta \omega_{i j t}$ is the first-differenced composite residual from equation (2). 
does not reject our instruments. Table 4 reports the covariance structure of firstdifferenced residuals associated with equation (2), $\Delta \omega_{i j t}$. First-differencing implies that $\Delta \omega_{i j t}$ lacks $\varphi_{i}$; i.e., it is defined only as a function of the remaining three components of the error term in equation (2). The results support our choice of instruments in Table 3.

\section{Insurance provision by the firm}

To quantify the insurance provided by firms to their workers we need first to estimate the sensitivity parameters, $\alpha$ and $\beta$, and then to estimate the different variance components of the error terms associated with equations (1) and (2). We report our main findings in Table 5.

We start by showing in Panel A the covariance structures in the matched sample of firms and workers, which contains 71580 observations. The first two columns report results similar to those shown in Tables 2 and 4 . The last column shows that the covariance between the worker's and the firm's lagged shocks is positive and significant, which is a first indication that firms do not provide full insurance to their workers.

To assess insurance within the firm we now focus our attention on the relation between changes in workers' residuals, $\Delta \omega_{i j t}$, and changes in the firms' residuals, $\Delta \epsilon_{j t}$. In what follows we borrow the formulation and estimation strategy proposed by Guiso et al. (2005), adjusting for the specificities of our analysis. Firms' error term, $\epsilon_{j t}$, is formulated as the sum of two components: a random walk and a $\operatorname{MA}(1)$, such that $\epsilon_{j t}=\zeta_{j t}+\tilde{\nu}_{j t}-\theta \tilde{\nu}_{j, t-1}$, where $\zeta_{j t}=\zeta_{j, t-1}+\tilde{u}_{j t}$. By assuming that $E\left(\tilde{u}_{j t}^{2}\right)=\sigma_{\tilde{u}}^{2}, E\left(\tilde{\nu}_{j t}^{2}\right)=\sigma_{\tilde{\nu}}^{2}$ for all $t, E\left(\tilde{\nu}_{j s} \tilde{\nu}_{j t}\right)=E\left(\tilde{u}_{j s} \tilde{u}_{j t}\right)=0$ for $s \neq t$, and $E\left(\tilde{\nu}_{j s} \tilde{u}_{j t}\right)=0$ for all $s$ and $t$, we expect that after two periods the autocovariance of $\Delta \epsilon_{j t}$ goes to zero. Empirically, Table 2 gives support to this specification, since we observe that autocovariances are zero for lags above 2, and non-zero for two or less lags. The last component of the error term in equation (2) is defined as $\psi_{i j t}=\vartheta_{i j t}+\xi_{i j t}-\lambda \xi_{i j, t-1}$, with $\vartheta_{i j t}=\vartheta_{i j, t-1}+\mu_{i j t}$. This specification is also not rejected by the results for the autocovariances in $\Delta \omega_{i j t}$, Table 4 . 
Table 5: Testing for insurance

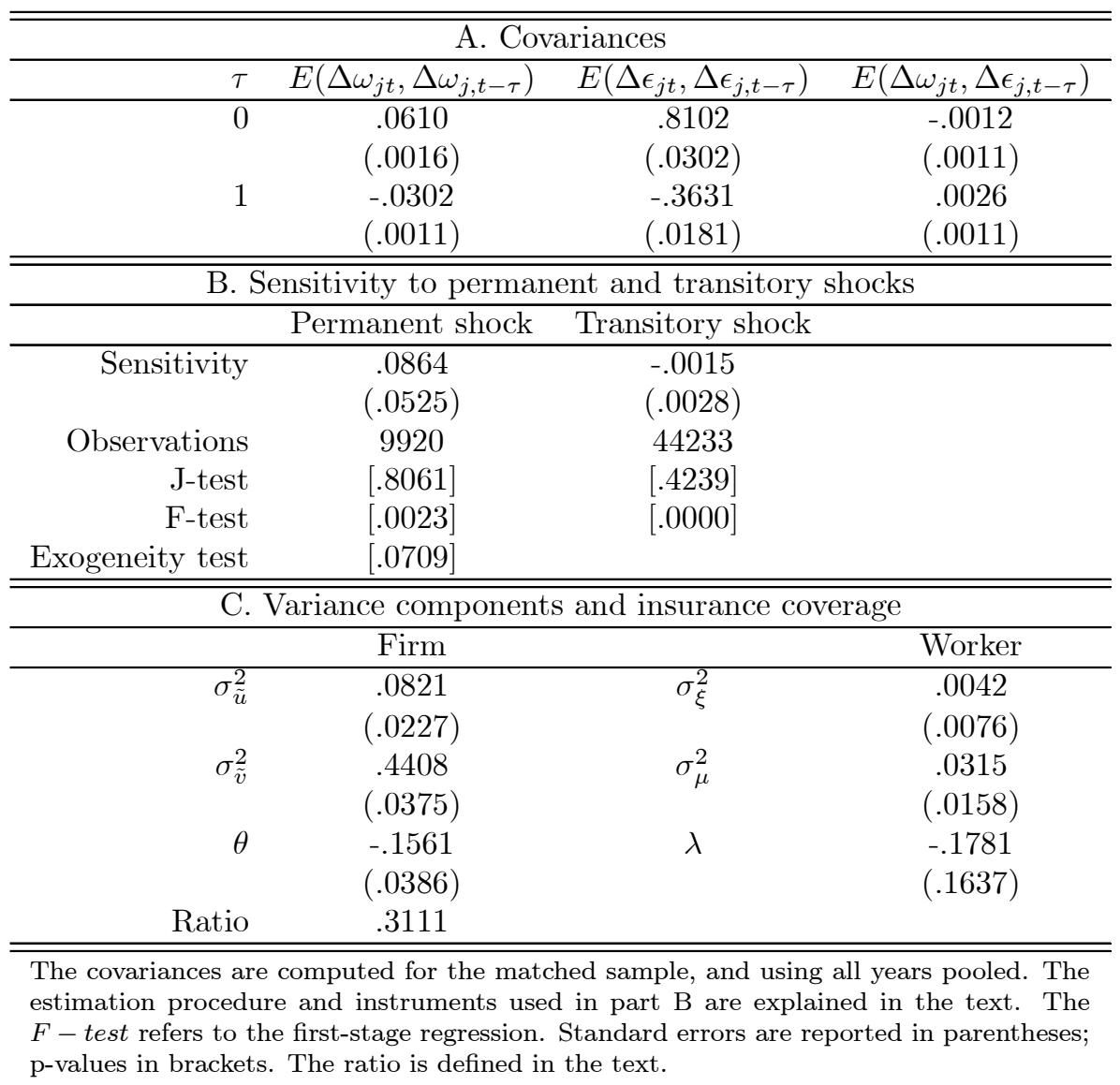

At the core of the estimation strategy lies an instrumental variables regression, whose specific instruments allow the identification of the parameters of interest; i.e. $\alpha$, the sensitivity of wages to permanent shocks, and $\beta$, the sensitivity of wages to transitory shocks. In both cases, the dependent variable is $\Delta \omega_{i j t}$, and the explanatory variable is $\Delta \epsilon_{j t}$. Consistent estimates of these variables are obtained from sales and wage regressions presented in Tables 1 and 3, respectively. Guiso et al. (2005) show that $\left(\sum_{\tau=-2}^{2} \Delta \epsilon_{j, t-\tau}\right)^{k}$ is a valid set of instruments to estimate $\alpha$, while the estimation of $\beta$ can be based on the instruments $\left(\Delta \epsilon_{j, t-\tau}\right)^{k}$.

To estimate both $\alpha$ and $\beta$ we have used the feasible efficient GMM procedure, controlling for error correlation within firms. ${ }^{2}$ In each regression the specific in-

\footnotetext{
${ }^{2}$ In the permanent shock regression we clearly reject the null hypothesis of homoskedastic error terms, which
} 
struments are defined for $\mathrm{k}=1, . ., 4$. For both regressions, a likelihood-ratio test rejects the null that the extra powers of the instruments are redundant. ${ }^{3}$ The overidentifying restriction tests do not reject the validity of instruments used in both regressions, and from the $F$-test we conclude that the instruments used in each regression are jointly significant. Finally, we performed the exogeneity test for $\Delta \epsilon_{j t}$ based on the difference in the Hansen-Sargan statistic between a model where it is assumed exogenous and our alternative model where we take it as endogenous. The test rejects the null that $\Delta \epsilon_{j t}$ is exogenous. This result implies that we also reject the equality between the sensitivity to both types of shocks.

We conclude from Panel B that workers' wages are not sensitive to transitory shocks on firms' performance, but they respond to firms' permanent shocks. ${ }^{4}$ The elasticity of wages to permanent shocks to firms' performance is .09 (compared to .07 in Guiso et al. (2005) for Italy).

Following the evidence provided by Altonji and Segal (1996), we estimated the different variance components using equally weighted minimum distance. Panel $\mathrm{C}$ reports the results. From Guiso et al. (2005), we can define the two variances associated with the shocks to sales as $\sigma_{u}^{2}=\sigma_{\tilde{u}}^{2} /(1-\rho)^{2}$ and $\sigma_{v}^{2}=\left(1+\theta^{2}\right) \sigma_{\tilde{v}}^{2}+(\rho /(1-\rho))^{2} \sigma_{\tilde{u}}^{2}$. These are the variances of the permanent shock and the transitory shock, respectively. We estimate that $\sigma_{u}^{2}$ is .56 , and $\sigma_{v}^{2}$ is .66 , which amounts to a considerable variability. The moving average coefficient is about -.16. All three estimates are statistically significant. For workers the variance of transitory shocks, $\sigma_{\xi}^{2}$, is .0042, but non-significant, while the variance of permanent shocks, $\sigma_{\mu}^{2}$, is significant and just above .03. The moving average parameter estimate is -.18 , and insignificant. These results are consistent with our analysis from Panel B. Our results also show that the different variances are considerably higher for firms than for workers.

In order to compute the portion of wage variability that can be attributed to

justifies the use of GMM. For example, the Pagan and Hall test discussed in Baum et al. (2003) has a $p$-value of .0279. For the transitory shock the evidence on heteroskedasticity is mixed. However, since our sample is large enough for asymptotic results to be valid, and given that IV gives inconsistent inference results if errors are in fact heteroskedastic, we adopted a conservative strategy and implemented also the GMM procedure in this case. The following conclusions on transitory shocks are not changed if we use generalized IV instead of GMM.

${ }^{3}$ The p-value of the tests is always below .001 .

${ }^{4}$ The $p$-value associated with the estimate .0864 is exactly .1 . 
firm's shock, Guiso et al. (2005) define the ratio $\sqrt{E\left\{\left[\left(\Delta \omega_{i j t}\right)^{2}\right] \mid j\right\}} / \sqrt{E\left[\left(\Delta \omega_{i j t}\right)^{2}\right]}$. We conclude that approximately $31 \%$ of the total variability in wages can be explained by firm-specific risk. For the Italian labor market, Guiso et al. conclude that this ratio is about $15 \%$. In comparison with Italy, Portugal also presents much higher variances of the shocks for both sales and wages. Combining the evidence gathered so far, we conclude that Portuguese firms provide less insurance to their workers, when compared to Italian firms, a result in line with the high wage flexibility pointed out by studies on Portugal.

Finally, we analyze heterogeneity in insurance provision by firms. Table 6 reports the sensitivity of wages to permanent and transitory shocks, taking into account different occupations (Manager), the volatility of firm sales (SDSales), the threat of bankruptcy, the origin of the capital (Foreign or national), firm size (FSize), the number of industries in which the firm operates (NInd), and its number of establishments (NEst). ${ }^{5}$ To estimate these regressions we implemented once more the GMM procedure used in Panel B of Table 5, and define the extra instruments as the previous instruments interacted with the new variables. The validity of the instruments used is not rejected in both regressions. Since we have multiple endogenous regressors, Shea's (1997) partial $R^{2}$ are reported. ${ }^{6}$

The main feature of these results is that managers are not fully insured against transitory shocks, as opposed to the rest of the workforce. However, managers and workers with other occupations receive equal protection against permanent shocks. Firms with higher variability in their sales offer more insurance to permanent changes in their performance. this result is in line with the reasoning by Guiso et al. (2005), who interpret sales variability as an indicator of noise in the precision of the signal the firm receives on the effort of its workers. A less precise signal would reduce the possibility of the firm to link the wage paid to the worker performance,

\footnotetext{
${ }^{5}$ Volatility is measured by the standard deviation of logarithm of sales for the period under analysis, firm size is defined by the logarithm of the number of employees, and Bankruptcy is the percentage of firms that go bankrupt in a given district and region.

${ }^{6} \mathrm{As}$ before, the different heteroskedasticity tests do not provide a unique answer for the transitory shock regression. For this regression only, if generalized IV is used instead of GMM the relevant change would be that the coefficient on $\Delta \epsilon_{j t} *$ Manager is no longer statistically significant. For the permanent shocks regression, the Pagan and Hall heteroskedasticity general test has a $p-v a l u e$ of .0857 for the permanent shock regression, while the Koenker test has a $p-$ value of .0660 .
} 
Table 6: Insurance heterogeneity

\begin{tabular}{|c|c|c|}
\hline & Permanent shock & $\overline{\text { Transitory shock }}$ \\
\hline \multirow{6}{*}{$\Delta \epsilon_{j t} *$ Manager } & .4343 & -.0164 \\
\hline & $(.2279)$ & $(.0151)$ \\
\hline & {$[.0123]$} & {$[.3676]$} \\
\hline & -.0616 & .0055 \\
\hline & $(.0404)$ & $(.0021)$ \\
\hline & {$[.0187]$} & {$[.3708]$} \\
\hline \multirow[t]{3}{*}{$\Delta \epsilon_{j t} *$ SDSales } & -.1070 & .0016 \\
\hline & $(.0453)$ & $(.0053)$ \\
\hline & {$[.0230]$} & {$[.3214]$} \\
\hline \multirow[t]{3}{*}{$\Delta \epsilon_{j t} *$ Bankruptcy } & -.0213 & -.0001 \\
\hline & $(.0182)$ & $(.0008)$ \\
\hline & {$[.0135]$} & {$[.4151]$} \\
\hline \multirow[t]{3}{*}{$\Delta \epsilon_{j t} *$ Foreign } & .1570 & .0057 \\
\hline & $(.0517)$ & $(.0071)$ \\
\hline & {$[.0193]$} & {$[.3607]$} \\
\hline \multirow[t]{3}{*}{$\Delta \epsilon_{j t} * F S i z e$} & -.0209 & .0030 \\
\hline & $(.0195)$ & $(.0035)$ \\
\hline & {$[.0182]$} & {$[.3467]$} \\
\hline \multirow[t]{3}{*}{$\Delta \epsilon_{j t} * N I n d$} & -.0478 & -.0036 \\
\hline & $(.0240)$ & $(.0082)$ \\
\hline & {$[.0362]$} & {$[.3032]$} \\
\hline \multirow[t]{3}{*}{$\Delta \epsilon_{j t} * N E s t$} & .0088 & -.0004 \\
\hline & $(.0149)$ & $(.0027)$ \\
\hline & {$[.0197]$} & {$[.3391]$} \\
\hline Observations & 8681 & 33055 \\
\hline J-test: $p$-value & .3631 & .7755 \\
\hline
\end{tabular}

The dependet variable is $\Delta \omega_{i j t}$. The instruments used in each regression are explained in the text. Robust standard errors reported in parentheses; Shea's (1997) partial $R^{2}$ in brackets. We account for within firm correlation of residuals. We report the J-test for the validity of the instruments. 
and therefore more wage insurance would be provided. Foreign firms provide less insurance to permanent shocks. Firms that diversify their activity among different industries offer on average a higher level of protection against permanent shocks.

\section{Conclusion}

The paper evaluated the impact of product market uncertainty on workers wages, relying on data of remarkable qualify to estimate dynamic panel data models. Results point to the rejection of the full insurance hypothesis. Workers' wages respond to permanent shocks to firm performance, whereas they are not sensitive to transitory shocks. Once we consider the heterogeneity of insurance provision across types of firms and workers, we find that managers are not fully insured against transitory shocks, while they receive the same protection against permanent shocks as workers in other occupations. Firms with a higher variability in their sales, and those that operate in different industries, offer more insurance against permanent shocks to their performance. We conclude that, in comparison to Italy, Portuguese firms provide less insurance to their workers, corroborating evidence previously reported on the high degree of wage flexibility in Portugal.

\section{References}

Abowd, John A. And Thomas Lemieux (1993). The effects of product market competition on collective bargaining agreements: the case of foreign competition in Canada. Quarterly Journal of Economics, 108(4): 983-1014.

Altonji, Joseph G. And Lewis M. Segal (1996). Small-sample bias in GMM estimation of covariance structures. Journal of Business and Economic Statistics, 14(3): 353-367.

Arellano, Manuel And Stephen Bond (1991). Some tests of specification for panel data: Monte Carlo evidence and an application to employment equations. Review of Economic Studies, 58(2): 277-297. 
Azariadis, Costas (1975). Implicit contracts and underemployment equilibria. Journal of Political Economy, 83(6): 1183-1202.

Baily, Martin Neil (1974). Wages and employment under uncertain demand. Review of Economic Studies, 41(1): 37-50.

Baum, Christopher F., Mark E. Schaffer, and Steven Stillman (2003). Instrumental variables and GMM: Estimation and testing. The Stata Journal, 3(1): 1-31.

Beaudry, Paul and John DiNardo (1991). The effects of implicit contracts on the movement of wages over the business cycle: evidence from micro data. Journal of Political Economy, 99(4): 665-688.

Blanchflower, David G., Andrew J. Oswald and Peter Sanfey (1996). Wages, profits and rent-sharing. Quarterly Journal of Economics, 111(1): 227-251.

Blundell, Richard And Stephen Bond (1998). Initial conditions and moment restrictions in dynamic panel data models. Journal of Econometrics, 87(1): 115-143.

Cappellari, Lorenzo (1999). Minimum distance estimation of covariance structures. Paper presented at the Conference of the Royal Statistical Society, London, UK, May 17.

Cardoso, Ana Rute (1999). Firm's wage policies and the rise in labor market inequality: the case of Portugal. Industrial and Labor Relations Review, 53(1): 87-102.

Cardoso, Ana Rute and Pedro Portugal (2005). Contractual wages and the wage cushion under different bargaining settings." Journal of Labor Economics, 23(4): 875-902.

Christofides, Louis N. And Andrew J. Oswald (1992). Real wage determination and rent-sharing in collective bargaining agreements. Quarterly 
Journal of Economics, 107(3): 985-1002.

Davidson, Russel and James G. MacKinnon (2004). Econometric Theory and Methods. New York: Oxford University Press.

Devereux, Paul J. (2005). Do employers provide insurance against low frequency shocks? Industry employment and industry wages. Journal of Labor Economics, 23(2): 313-340.

Estevão, Marcello and Stacey Tevlin (2003). Do firms share their success with workers? The response of wages to product market conditions. Economica, 70: 597-617.

GAMBER, EDWARD N. (1988). Long-term risk-sharing wage contracts in an economy subject to permanent and temporary shocks. Journal of Labor Economics, 6(1): 83-99.

Gordon, Donald F. (1974). A neo-classical theory of keynesian unemployment. Economic Inquiry, 12(4): 431-459.

Guiso, Luigi, Luigi Pistaferri, and Fabiano Schivardi (2005). Insurance within the firm. Journal of Political Economy, 113(5): 1054-1087.

Harris, Milton and Bengt Holmstrom (1982). "A theory of wage dynamics." Review of Economic Studies, 49(3): 315-333.

Hildreth Andrew K. G. And Andrew J. Oswald (1997). "Rent-sharing and wages: evidence from company and establishment panels." Journal of Labor Economics, 15(2): 318-337.

Holmstrom, Bengt (1981). Contractual models of the labor market. American Economic Review, 71(2): 308-313.

Holzer, Harry J. And Edward B. Montgomery (1993). "Asymmetries and rigidities in wage adjustments bt firms." Review of Economics and Statistics, 75(3): 397-408. 
Knight, Frank H. (1921). Risk, Uncertainty and Profit. Boston: Houghton Mifflin.

Meghir, Costas And Luigi Pistaferri (2004). Income variance dynamics and heterogeneity. Econometrica, 72(1): 1-32.

Nickell, Stephen And Sushil Wadhwani (1990). Insider forces and wage determination. Economic Journal, 100(401): 496-509.

OECD [Organisation for Economic Co-operation and Development] (1992). OECD Economic Surveys, Portugal, 1991/92. Paris: OECD.

OECD [Organisation for Economic Co-operation and Development] (1994). OECD Employment Outloook 1994. Paris: OECD.

OECD [Organisation For ECONOMIC CO-Operation AND DEvElopment] (1999). OECD Employment Outlook 1999. Paris: OECD.

Portugal, Ministério do Trabalho E Da Segurança Social (1986 to 1999). Quadros de Pessoal. Data in magnetic media.

Rosen, SHerwin (1985). Implicit contracts: a survey. Journal of Economic Literature, 23(3): 1144-1175.

SheA, John (1997). Instrument relevance in multivariate linear models: a simple measure. Review of Economics and Statistics, 79(2): 348-352.

Thomas, Jonathan and Tim Worrall (1988). Self-enforcing wage contracts. Review of Economic Studies, 55(4): 541-553.

WEINBERG, BRUCE (2001). Long-term wage fluctuations with industry-specific human capital. Journal of Labor Economics, 19(1): 231-264.

WeISS, YorAm (1984). Wage contracts when output grows stochastically: the roles of mobility costs and capital market imperfections. Journal of Labor Economics, 2(2): 155-173. 
Windmeijer, Frank (2005). A finite sample correction for the variance of linear efficient two-step GMM estimators. Journal of Econometrics, 126: 25-51.

\section{Appendix: Longitudinal linked employer-employee data set Checks on the consistency of data}

After merging the worker data across years, inconsistencies were identified if the worker gender or date of birth was reported changing, or if the highest schooling level achieved was reported decreasing over time. In that case, the information reported over half the times has been taken as the correct one ${ }^{7}(0.8 \%, 2.3 \%, 5.2 \%$ of the observations have been corrected, respectively for gender, birth date and education). Workers with inconsistent data after the introduction of the previous corrections were dropped. The whole information on the worker was dropped, whichever the incorrect number of observations identified $(1.7 \%, 1.1 \%$, and $4.3 \%$ of the observations, respectively for gender, birth date and schooling). Workers with missing age or schooling after the introduction of the previous corrections were dropped (respectively $0.7 \%$ and $1.7 \%$ of the observations, corresponding to $2.1 \%$ and $2 \%$ of the workers).

\section{Constraints imposed}

The analysis focuses on workers and firms in manufacturing and services private sector in mainland Portugal.

On the worker side, we have retained wage-earners working full-time, aged 18 to 65 , whose wage is not below the national minimum wage ${ }^{8}$ (which led to dropping $20 \%, 2 \%$, and $3 \%$ of the dataset, respectively). Outliers in wage growth have been dropped ${ }^{9}$, which corresponded to a very small share of the data base, $0.03 \%$. Workers observed just once in the database cannot be considered in the estimation of the models used (and thus 5\% have been dropped). This is the full set of workers, which comprises over ten million observations. Due to the large size of the full

\footnotetext{
${ }^{7}$ Note that this requirement is more demanding than just considering the modal value as the accurate one.

${ }^{8}$ May drop apprentices and handicapped workers.

${ }^{9} \log$ difference in real wages either greater than 2 or smaller than -.5
} 
data set it was not feasible to run the worker computations on the full data set and we have therefore used a 2 percent random sample of workers (keeping all the yearly observations for the selected workers). Descriptive statistics on this sample, comprising 205,929 yearly observations on 42,008 workers, are presented in table $7 .{ }^{10}$

On the firm side, we have kept firms operating full-year, and whose sales are not missing or outlier ${ }^{11}$ (thus dropping $3 \%, 9 \%$, and $0.2 \%$ of the firms, respectively). ${ }^{12}$ Firms that were ever larger than 20 workers have been kept for analysis, since they are more likely to be run in entrepreneurial terms. Given the very small size structure of the firms in the Portuguese economy, this led to keeping $12 \%$ of the firms. The set of firms under analysis comprises 131,100 yearly observations on 18,366 firms. Descriptive statistics are reported in table $8 .^{13}$

Table 7: Descriptive statistics on workers

\begin{tabular}{lcc}
\hline \multicolumn{1}{c}{ Variable } & Mean & Std. Dev. \\
\hline Log real monthly wage (PTE) & 11.63 & 0.50 \\
Age & 36.3 & 10.95 \\
Gender (female) & 0.39 & \\
Education & & \\
$\quad$ 4 years & 0.46 & \\
6 years & 0.22 & \\
9 years & 0.13 & \\
High School & 0.14 & \\
University & 0.05 \\
Occupation & & \\
managers & 0.02 & \\
professionals & 0.02 & \\
middle manag, technic. & 0.09 \\
administrative & 0.14 \\
service, sales & 0.11 \\
skilled & 0.27 \\
machine operat., assembly & 0.14 \\
$\quad$ unskilled & 0.15 \\
$\quad$ unknown & 0.05 \\
Industry & \\
food, bev, tob. & 0.05 \\
\hline
\end{tabular}

\footnotetext{
${ }^{10}$ The dynamics in the models under estimation determine that a smaller number of individuals will be considered in the regressions.

${ }^{11} \log$ difference in real wages either greater than 5 or smaller than -5 .

${ }^{12}$ Firms in the first few months of their existence, not yet one year, were excluded, to avoid capturing sales fluctuations that are due to part-year operation.

${ }^{13}$ The dynamics in the models under estimation determine that a smaller number of firms will be considered in the regressions.
} 


\begin{tabular}{|c|c|c|}
\hline Variable & Mean & Std. Dev. \\
\hline textiles & 0.17 & \\
\hline wood & 0.04 & \\
\hline chemicals & 0.05 & \\
\hline mineral products & 0.15 & \\
\hline construction & 0.10 & \\
\hline trade & 0.21 & \\
\hline restaurants, hotels & 0.06 & \\
\hline transport, communic. & 0.04 & \\
\hline banking, insurance, business serv. & 0.09 & \\
\hline other serv. & 0.05 & \\
\hline \multicolumn{3}{|l|}{ Region } \\
\hline North Coast & 0.34 & \\
\hline Center Coast & 0.16 & \\
\hline Lisbon & 0.4 & \\
\hline Inland & 0.08 & \\
\hline Algarve & 0.03 & \\
\hline $\mathrm{N}$ & & 05199 \\
\hline
\end{tabular}

Table 8: Descriptive statistics on firms

\begin{tabular}{lcc}
\hline \multicolumn{1}{c}{ Variable } & Mean & Std. Dev. \\
\hline Log real sales (1000 PTE) & 12.93 & 1.45 \\
Number workers in firm & 58.23 & 170.8 \\
Number of establishments in firm & 2.25 & 9 \\
Number of industries in firm & 1.09 & 0.38 \\
Share firms bankrupt in province & 0.09 & 0.04 \\
Variability firm sales over time: sd log real sales & 0.5 & 0.51 \\
Industry & & \\
food, bev, tob. & 0.05 & \\
textiles & 0.19 & \\
wood & 0.05 & \\
chemicals & 0.06 & \\
mineral products & 0.15 & \\
construction & 0.11 & \\
trade & 0.2 & \\
restaurants, hotels & 0.04 & \\
transport, communic. & 0.04 & \\
banking, insurance, business serv. & 0.06 & \\
other serv. & 0.05 & \\
Region & & \\
North Coast & 0.34 & \\
Center Coast & 0.18 & \\
Lisbon & 0.37 & \\
Inland & 0.08 & \\
Algarve & 0.03 & \\
Origin of capital & & \\
national & 0.94 & \\
foreign & 0.06 & \\
& & \\
\hline
\end{tabular}




\section{Most Recent Working Papers}

\begin{tabular}{|c|c|}
\hline NIPE WP 17/2005 & $\begin{array}{l}\text { Cardoso, Ana Rute and Miguel Portela, The provision of wage } \\
\text { insurance by the firm: evidence from a longitudinal matched } \\
\text { employer-employee dataset, } 2005 \text {. }\end{array}$ \\
\hline NIPE WP 16/2005 & $\begin{array}{l}\text { Ribeiro, J. Cadima and J. Freitas Santos, Dilemas competitivos da } \\
\text { empresa nacional: algumas reflexões, } 2005 \text {. }\end{array}$ \\
\hline NIPE WP 15/2005 & $\begin{array}{l}\text { Ribeiro, J. Cadima and J. Freitas Santos, No trilho de uma nova } \\
\text { política regional, } 2005 \text {. }\end{array}$ \\
\hline NIPE WP 14/2005 & $\begin{array}{l}\text { Alexandre, Fernando, Pedro Bação and Vasco J. Gabriel, On the } \\
\text { Stability of the Wealth Effect, } 2005 \text {. }\end{array}$ \\
\hline NIPE WP 13/2005 & $\begin{array}{l}\text { Coelho, César, Francisco José Veiga and Linda G. Veiga, Political } \\
\text { Business Cycles in Local Employment, } 2005 .\end{array}$ \\
\hline NIPE WP 12/2005 & $\begin{array}{l}\text { Veiga, Francisco José and Ari Aisen, The Political Economy of } \\
\text { Seigniorage, 2005. }\end{array}$ \\
\hline NIPE WP 11/2005 & $\begin{array}{l}\text { Silva, João Cerejeira, Searching, Matching and Education: a Note, } \\
2005 \text {. }\end{array}$ \\
\hline NIPE WP 10/2005 & $\begin{array}{l}\text { de Freitas, Miguel Lebre, Portugal-EU Convergence Revisited: } \\
\text { Evidence for the Period 1960-2003, } 2005 .\end{array}$ \\
\hline NIPE WP 9/2005 & $\begin{array}{l}\text { Sousa, Ricardo M., Consumption, (Dis) Aggregate Wealth and Asset } \\
\text { Returns, } 2005 .\end{array}$ \\
\hline NIPE WP 8/2005 & $\begin{array}{l}\text { Veiga, Linda Gonçalves and Maria Manuel Pinho, The Political } \\
\text { Economy of Portuguese Intergovernmental Grants, } 2005 \text {. }\end{array}$ \\
\hline NIPE WP 7/2005 & $\begin{array}{l}\text { Cortinhas, Carlos, Intra-Industry Trade and Business Cycles in } \\
\text { ASEAN, } 2005 .\end{array}$ \\
\hline NIPE WP 6/2005 & $\begin{array}{l}\text { Mourão, Paulo Reis, Que Critérios Redistributivos na Lei das } \\
\text { Finanças Locais?, 2005. }\end{array}$ \\
\hline NIPE WP 5/2005 & $\begin{array}{l}\text { Mourão, Paulo Reis, Elasticities of Regional and Local } \\
\text { Administrations Expenditures - the Portuguese case, 2005. }\end{array}$ \\
\hline NIPE WP 4/2005 & $\begin{array}{l}\text { Mourão, Paulo Reis, Incentivos à Localização em Trás-os-Montes e } \\
\text { Alto Douro (os séculos XII - XVI), } 2005 .\end{array}$ \\
\hline NIPE WP 3/2005 & $\begin{array}{l}\text { Alexandre, Fernando and Pedro Bação, Monetary Policy and Asset } \\
\text { Prices: the investment channel, } 2005 \text {. }\end{array}$ \\
\hline NIPE WP 2/2005 & $\begin{array}{l}\text { Conraria, Luís Aguiar and Yi Wen, Understandig the Impact of Oil } \\
\text { Shocks, } 2005 .\end{array}$ \\
\hline
\end{tabular}

